\title{
BIOACTIVE COMPOUNDS DURING THE MATURATION OF FOUR FRUITS NATIVE TO THE RESTINGA FOREST OF CEARA ${ }^{1}$
}

\author{
NIGÉRIA PEREIRA GONÇALVES², ELISEU MARLÔNIO PEREIRA DE LUCENA ${ }^{3}$, \\ ORIEL HERRERA BONILLA ${ }^{4}$, MÁRCIA RÉGIA SOUZA DA SILVEIRA ${ }^{5}$, \\ FRANCISCA JÉSSICA COSTA TAVARES
}

\begin{abstract}
Fruits provide not only essential nutrients for food, but also bioactive compounds that promote health benefits and help reducing the risk of developing non-communicable chronic diseases. In this sense, this work aimed at quantifying bioactive compounds during the maturation of four fruits native to the Restinga forest of Ceara. Myrtle fruits (Eugenia punicifolia (Kunth) DC.) were collected at the Botanical State Park of Ceara, Caucaia-CE, and guajiru (Chrisobalanus icaco L.), manipuça (Mouriri cearensis Huber) and murici-pitanga fruits (Byrsonima gardneriana A. Juss.) at the Botanical Garden of São Gonçalo, São Gonçalo do Amarante-CE. Fruits were collected at different stages (E) and transported to the Laboratory of Plant Ecophysiology, being characterized into five or six maturation stages according to the bark color, then processed and frozen for the following physicochemical and chemical evaluations: ascorbic acid, total chlorophyll, total carotenoids, total anthocyanins and yellow flavonoids. A completely randomized design was used, with five or six treatments, depending on the maturation stages of fruits and four replicates. Murici-pitanga had higher contents of ascorbic acid (ascorbic acid $646.23 \mathrm{mg} / 100 \mathrm{~g} \mathrm{E}_{5}$ ), total carotenoids $\left(6.13 \mathrm{mg} / 100 \mathrm{~g} \mathrm{E}_{5}\right)$ and total anthocyanins $\left(7.99 \mathrm{mg} / 100 \mathrm{~g} \mathrm{E}_{2}\right)$; and myrtle had higher contents of total chlorophyll $\left(11.05 \mathrm{mg} / 100 \mathrm{~g} \mathrm{E}_{1}\right)$ and yellow flavonoid $\left(69.11 \mathrm{mg} / 100 \mathrm{~g} \mathrm{E}_{2}\right)$. There are positive and significant correlations between chlorophyll and carotenoid $(\mathrm{R}=0.99 ; \mathrm{P}<0.01)$ for manipuça and between anthocyanin and yellow flavonoid $(\mathrm{R}=0.97 ; \mathrm{P}<0.05)$ for murici-pitanga fruits; however, the correlation is negative and significant between ascorbic acid and yellow flavonoids $(\mathrm{R}=-0.98 ; \mathrm{P}<0.05)$ for myrtle fruits. It could be concluded that murici-pitanga and myrtle fruits had the highest contents of bioactive compounds with the highest levels, therefore both fruits can be recommended to be commercially exploited by the food, cosmetic and phytomedicine sectors.
\end{abstract}

Index terms: ascorbic acid, chlorophyll, carotenoids, anthocyanins, yellow flavonoids.

\section{COMPOSTOS BIOATIVOS DURANTE A MATURAÇÃO DE QUATRO FRUTAS NATIVAS DA RESTINGA CEARENSE}

RESUMO - As frutas fornecem não somente nutrientes essenciais à alimentação, mas também compostos bioativos que promovem benefícios à saúde e auxiliam na redução do risco de desenvolvimento de doenças crônicas não transmissíveis. Neste mesmo sentido, o presente trabalho objetivou quantificar os compostos bioativos durante a maturação de quatro frutas nativas da Restinga cearense. Os frutos da murta (Eugenia punicifolia (Kunth) DC.) foram colhidos no Parque Estadual Botânico do Ceará, em Caucaia-CE, e os do guajiru (Chrisobalanus icaco L.), do manipuçá (Mouriri cearensis Huber) e do murici-pitanga (Byrsonima gardneriana A. Juss.) no Jardim Botânico de São Gonçalo, em São Gonçalo do Amarante-CE. Os frutos foram coletados em diferentes estádios (E) e transportados ao Laboratório de Ecofisiologia Vegetal, sendo caracterizados em cinco ou seis estádios de maturação, de acordo com a coloração da casca, depois processados e congelados para as avaliações físico-químicas e químicas: ácido ascórbico, clorofila total, carotenoides totais, antocianinas totais e flavonoides amarelos. Utilizou-se do delineamento inteiramente casualizado, com cinco ou seis tratamentos, dependendo dos estádios de maturação do fruto, e quatro repetições. $\mathrm{O}$ fruto do murici-pitanga foi superior para ácido ascórbico (646,23 mg ácido ascórbico/100 g no $\mathrm{E}_{5}$ ), carotenoides totais $\left(6,13 \mathrm{mg} / 100 \mathrm{~g}\right.$ no $\left.\mathrm{E}_{5}\right)$ e antocianinas totais $\left(7,99 \mathrm{mg} / 100 \mathrm{~g}\right.$ no $\left.\mathrm{E}_{2}\right)$; e o fruto da murta foi superior para clorofila $\left(11,05 \mathrm{mg} / 100 \mathrm{~g}\right.$ no $\left.\mathrm{E}_{1}\right)$ e flavonoides amarelos $\left(69,11 \mathrm{mg} / 100 \mathrm{~g}\right.$ no $\left.\mathrm{E}_{2}\right)$. Existem correlações positivas e significativas entre clorofila e carotenoides $(\mathrm{R}=0,99 ; \mathrm{P}<0,01)$ para o manipuçá, e entre antocianina e flavonoides amarelos $(\mathrm{R}=0,97 ; \mathrm{P}<0,05)$ para o murici-pitanga; no entanto, a correlação é negativa e significativa entre ácido ascórbico e flavonoides amarelos $(\mathrm{R}=-0,98 ; \mathrm{P}<0,05)$ na murta. Conclui-se que o murici-pitanga e a murta têm os maiores números de compostos bioativos com os níveis mais altos; portanto, ambos os frutos podem ser recomendados para serem explorados comercialmente pelos setores de alimentação, cosméticos e fitoterápicos.

Termos para indexação: ácido ascórbico, clorofila, carotenoides, antocianinas, flavonoides amarelos.

\footnotetext{
1(Paper 112-16). Received September 12, 2016. Accepted January 25, 2017.

${ }^{2}$ Master in Natural Resources, State University of Ceara - UECE, Fortaleza-CE, Brazil. E-mail: nibotanica@gmail.com

${ }^{3} \mathrm{PhD}$ in Agronomy, Adjunct Professor of Biological Sciences Course, CCS/UECE, Fortaleza-CE, Brazil. E-mail: eliseu.lucena@uece.br ${ }^{4} \mathrm{PhD}$ in Ecology, Associate Professor of Biological Sciences Course, CCS/UECE, Fortaleza-CE, Brazil. E-mail: oriel.herrera@uece.br ${ }^{5}$ Master in Food Science and Technology, Analyst at the Laboratory of Post-Harvest Physiology and Technology, Embrapa Tropical Agroindustry, Fortaleza-CE, Brazil. E-mail: marcia.silveira@embrapa.br

${ }^{6}$ Bachelor in Biological Sciences, State University of Ceara - UECE, Fortaleza-CE, Brazil. E-mail: jessika_te10@hotmail.com
} 


\section{INTRODUCTION}

Fruits provide an important source of bioactive molecules. For this reason, their consumption contributes to benefits to human health, such as the prevention of cardiovascular diseases and cancer (MORAIS et al., 2015).

Due to the richness of their nutrients, epidemiological studies recommend their frequent ingestion, since the beneficial effects include the reduction of the appearance of several diseases, such as cardiovascular diseases, some cancers, AIDS and others associated with the aging process (cataract, Alzheimer's disease and other disorders of the nervous system). The protective effect in which it is attributed is related to the variety of antioxidant substances present in fruits, such as vitamins $\mathrm{C}$ and $\mathrm{E}$, phenolic compounds (flavonoids) and carotenoids ( $\beta$-carotene) (KRUMREICH et al., 2015).

Numerous plant species produce bioactive compounds that can play important roles in maintaining health, although seasonal and environmental variations, soil type and plant age associated with propagation difficulties of certain species may limit the availability of many bioactive compounds and restrict further investigation of their properties (CASTRO et al., 2016).

Guajiru (Chrisobalanus icaco L.) belongs to the family Chrysobalanaceae and has as fruit a drupe very appreciated for its unique flavor among coastal fruit trees; manipuça (Mouriri cearensis Huber) is a Melastomataceae native to the Restinga Forest of Ceara, which has berry-type fleshy fruits with sweet taste; murici-pitanga (Byrsonima gardneriana A. Juss.) belongs to the family Malpighiaceae with very tasty drupe-type fruit, being consumed fresh or in the form of juices, ice creams, liqueurs, jellies and sweets in coastal communities; myrtle (Eugenia punicifolia (Kunth) DC.) is Myrtaceae characteristic of the Coastal Tablelands and has berry-type fleshy fruit with edible and acid pulp, and can be consumed fresh or in the form of juices, jellies, liqueurs and sweets (LUCENA et al., 2011).

The contents of ascorbic acid, total chlorophyll, total carotenoids, total anthocyanins and yellow flavonoids of guajiru, manipuça, murici-pitanga and myrtle fruits have not yet been determined, except for ascorbic acid for manipuça, as according to Garcia et al. (2011), the content of ascorbic acid in manipuça decreased with maturation advancement, i.e., it ranged from 3.05 to 2.19 $\mathrm{mg} / 100 \mathrm{~g}$ in maturation stages 1 and 5 , respectively. According to the authors, the knowledge of the physical and chemical properties of foods is of fundamental importance to evaluate the availability of nutrients and which can act as functional foods in order to obtain balanced and nutritious diet.

In this context, the present work aimed at quantifying bioactive compounds during the maturation of four fruits native to the Restinga forest of Ceara: C. icaco, M. cearensis, B. gardneriana and E. punicifolia, aiming at their use in cosmetics and herbal products, as well as to provide a healthier diet.

\section{MATERIAL AND METHODS}

Myrtle fruits were collected at the Ceara Botanical State Park, Caucaia-CE, whose coordinates are $3^{\circ} 44^{\prime} 10^{\prime \prime} \mathrm{S}$ and $38^{\circ} 39^{\prime} 11^{\prime \prime} \mathrm{W}$, consisting of Restinga, Caatinga and Mangrove, with minimum precipitation in August to October $(0.0 \mathrm{~mm})$ and maximum in May (157.4 mm) (FUNCEME; IPECE, 2015), and Equatorial climate of Savana with Dry Summer (As) according to the Köppen-Geiger climatic classification (KOTTEK et al., 2006).

Guajiru, manipuça and murici-pitanga fruits were collected at the Botanical Garden of São Gonçalo, São Gonçalo do Amarante-CE, located at coordinates $3^{\circ} 36^{\prime} 26^{\prime \prime} \mathrm{S}$ and $38^{\circ} 58^{\prime}$ ' $06^{\prime}$ ” $\mathrm{W}$, consisting of Restinga forest, with minimum precipitation in August $(1.5 \mathrm{~mm})$ and maximum in April (281.8 $\mathrm{mm}$ ) (FUNCEME; IPECE, 2015), and Equatorial climate of Savana with Dry Summer (As) according to Köppen-Geiger classification (KOTTEK et al., 2006).

The fruits of the four native species of the Ceara coast were manually and randomly collected from 10 previously selected matrixes of each plant species, with approximately $2.5 \mathrm{~kg}$ of fruits per maturation stage. Guajiru and the manipuça fruits were characterized into five maturation stages (E) according to the bark color, whereas muricipitanga and myrtle fruits were characterized into six maturation stages ( $\mathrm{E}_{1}$-very immature, $\mathrm{E}_{2}$-moderately immature, $\mathrm{E}_{3}$-immature, $\mathrm{E}_{4}$-mature, $\mathrm{E}_{5}$-mature and $\mathrm{E}_{6-}$ senescent).

In fruits, maturation stages varied according to the bark color: guajiru-100\% light green $\left(\mathrm{E}_{1}\right), 75 \%$ light green and $25 \%$ purple $\left(\mathrm{E}_{2}\right), 50 \%$ light green and $50 \%$ purple $\left(\mathrm{E}_{3}\right), 90 \%$ purple and $10 \%$ yellow $\left(\mathrm{E}_{4}\right)$ and $100 \%$ purple $\left(\mathrm{E}_{5}\right)$; manipuça- $100 \%$ dark green $\left(E_{1}\right), 100 \%$ light green $\left(E_{2}\right) 75 \%$ light green and $25 \%$ orange $\left(\mathrm{E}_{3}\right), 90 \%$ orange and $10 \%$ light green $\left(\mathrm{E}_{4}\right)$ and $100 \%$ orange $\left(\mathrm{E}_{5}\right)$; murici-pitanga-100\% light green $\left(E_{1}\right), 100 \%$ light green $\left(E_{2}\right), 50 \%$ light green and $50 \%$ orange $\left(E_{3}\right), 75 \%$ orange and $25 \%$ light green $\left(E_{4}\right)$, $100 \%$ orange $\left(\mathrm{E}_{5}\right), 100 \%$ red $\left(\mathrm{E}_{6}\right)$; myrtle- $100 \%$ dark 
green $\left(\mathrm{E}_{1}\right), 100 \%$ light green and $50 \%$ yellow $\left(\mathrm{E}_{2}\right)$, $75 \%$ orange and $25 \%$ yellow $\left(\mathrm{E}_{3}\right) ; 100 \%$ orange $\left(\mathrm{E}_{4}\right)$, $100 \%$ light red $\left(\mathrm{E}_{5}\right)$ and $100 \%$ dark red $\left(\mathrm{E}_{6}\right)$.

Seeds were then removed from fruits and the pulp was processed and frozen in freezer at $-20^{\circ} \mathrm{C}$ \pm 1 , to finally be analyzed regarding the contents of ascorbic acid (AA), total chlorophyll (CL), total carotenoids (CA), total anthocyanins (AN) and yellow flavonoids (FL).

The ascorbic acid content was obtained by titration with DFI solution $(2,6$ dichlorophenolindofenol $0.02 \%$ ) according to Strohecker and Henning (1967).

Chlorophyll and total carotenoids were determined by the method of Lichtenthaler (1987).

Determinations of total anthocyanins and yellow flavonoids followed the methodology of Francis (1982).

Guajiru and manipuça were characterized in five maturation stages, while murici-pitanga and myrtle were characterized in six maturation stages.

The experimental design was completely randomized, with five treatments (maturation stages) for guajiru and manipuça and six treatments for murici-pitanga and myrtle, with four replicates consisting of 200 fruits each. The results were submitted to analysis of variance observing the significance by the $\mathrm{F}$ test, and when significant, the Tukey test was carried out at 5\% probability level, using the Statistical Analysis System software $<$ V.1.0 $>$ - ESTAT. To verify linear correlations between variables, significance was verified by the $t$ test, using the Assistat 7.7 beta statistic software.

\section{RESULTS AND DISCUSSION}

The amount of ascorbic acid (AA) in guajiru fruits showed variations with minimum of 190.54 $\mathrm{mg}$ ascorbic acid/100 $\mathrm{g}$ of pulp in $\mathrm{E}_{5}$ and maximum of $284.63 \mathrm{mg}$ ascorbic acid/100 $\mathrm{g}$ of pulp in $\mathrm{E}_{3}$; for manipuça fruits, minimum value of $196.68 \mathrm{mg}$ ascorbic acid/100 $\mathrm{g}$ of pulp was obtained in $\mathrm{E}_{3}$ and maximum for $\mathrm{E}_{1}$ was $243.09 \mathrm{mg}$ ascorbic acid/100 $\mathrm{g}$ of pulp; the minimum obtained was $\mathrm{E}_{1}$, with 255.39 $\mathrm{mg}$ ascorbic acid/100 $\mathrm{g}$ and maximum in $\mathrm{E}_{5}$, with $646.23 \mathrm{mg}$ ascorbic acid/100 g; and in myrtle fruits, the minimum obtained was in $\mathrm{E}_{1}$, with $314.61 \mathrm{mg}$ ascorbic acid/100 $\mathrm{g}$ and maximum in $\mathrm{E}_{4}$, with 366.42 $\mathrm{mg}$ ascorbic acid/100 g (Figure 1A). Therefore, all native fruits studied met the recommended daily intake of vitamin $\mathrm{C}$ (ascorbic acid) for adults, which is $45 \mathrm{mg}$ according to RDC 269 (BRASIL, 2005), since they contain this amount in less than $100 \mathrm{~g}$ of tissue.
According to Chitarra and Chitarra (2005), the AA content tends to decrease with maturation and storage of many fruits due to the action of the enzyme ascorbic acid oxidase (ascorbinase), or the action of oxidizing enzymes such as peroxidase. On the other hand, degradation of cell wall polysaccharides through $\alpha$-galactosidase and $\beta$-galactosidase enzymes may result in the increase of galactose, which is one of the precursors of AA biosynthesis, promoting in some fruits the increase of AA during maturation (WHEELER et al., 1998; SMIRNOFF et al., 2001).

The behavior observed in this experiment for AA levels in manipuça fruits is decreasing with maturation (from $243.09 \mathrm{mg} / 100 \mathrm{~g}$ in $\mathrm{E}_{1}$ to 227.22 $\mathrm{mg} / 100 \mathrm{~g}$ in $\mathrm{E}_{5}$ ), which is similar to that reported by Garcia et al. (2011) in a work carried out also with manipuça (from $3.05 \mathrm{mg} / 100 \mathrm{~g}$ in $\mathrm{E}_{1}$ to $2.19 \mathrm{mg} / 100$ $\mathrm{g}$ in $\mathrm{E}_{5}$ ), although the values are much lower, which difference can be attributed to the location of plants, types of soils, harvest season and handling of fruits.

The daily inclusion of fruits rich in AA (vitamin C) in the diet is important for human nutrition, because according to Brasil (2006), in addition to increasing the organic absorption of iron of plant origin and helping to prevent iron deficiency anemia and scurvy, AA is a potent antioxidant, contributing to the body's defenses. In this sense, Souza et al. (EI-862) studied three mature acerola clones (Malpighia emarginata DC.) for AA content and obtained minimum and maximum values in four maturation stagers (I, II, III and IV); Florida Sweet cultivar $\left(\mathrm{E}_{\mathrm{IV}}-862.86\right.$ and $\left.\mathrm{E}_{\mathrm{I}}-1.501 .17 \mathrm{mg} / 100 \mathrm{~g}\right)$, Flor Branca cultivar $\left(\mathrm{E}_{\mathrm{IV}}-1.104 .57\right.$ and $\mathrm{E}_{\mathrm{I}}-1.966 .44$ $\mathrm{mg} / 100 \mathrm{~g})$ and BRS 366 cultivar $\left(\mathrm{E}_{\mathrm{III}}-1.328 .40\right.$ and $\mathrm{E}_{\mathrm{I}}-2.534 .06 \mathrm{mg} / 100 \mathrm{~g}$ ); therefore, these values are higher than those obtained for murici-pitanga in this study $\left(\mathrm{E}_{1}-255.39\right.$ and $\left.\mathrm{E}_{5}-646.23 \mathrm{mg} / 100 \mathrm{~g}\right)$ and decreasing with maturation, whereas for muricipitanga, values are increasing up to $\mathrm{E}_{5}$ and decreases in $\mathrm{E}_{6}$.

The AA content of myrtle fruit pulp increased with maturation advancement in this study (from $314.61 \mathrm{mg} / 100 \mathrm{~g}$ in $\mathrm{E}_{1}$ to $338.74 \mathrm{mg} / 100 \mathrm{~g}$ in $\mathrm{E}_{6}$ ). Increased AA contents (from $113.91 \mathrm{mg} / 100 \mathrm{~g}$ in $\mathrm{E}_{1}$ to $160.62 \mathrm{mg} / 100 \mathrm{~g}$ in $\mathrm{E}_{5}$ ) with maturation advancement were also reported for myrtle (Eugenia gracillima Kiaersk.) (ARAUJO et al., 2016). Higher AA values were observed by Lima et al. (2016), who studied the physicochemical characterization of myrtle fruits (Blepharocalyx salicifolius (Kunth) O.Berg) native to the region of Ibiapaba-CE and verified $369.1 \mathrm{mg} / 100$ g. Cavalini et al. (1985) also found an increase in AA content in Kumagai (Psidium guajava L.) guavas during maturation $\left(132.85 \mathrm{mg} / 100 \mathrm{~g}\right.$ in $\mathrm{E}_{1}$ and 162.85 
$\mathrm{mg} / 100 \mathrm{~g}$ in $\mathrm{E}_{5}$ ).

The amount of chlorophyll (CL) decreased during maturation of fruits, except for murici-pitanga fruits, which values oscillated (Figure 1B). Guajiru fruits obtained minimum of $4.77 \mathrm{mg} / 100 \mathrm{~g}$ in $\mathrm{E}_{3}$ and maximum of $9.80 \mathrm{mg} / 100 \mathrm{~g}$ in $\mathrm{E}_{2}$; in manipuça fruits, minimum of $1.90 \mathrm{mg} / 100 \mathrm{~g}$ in $\mathrm{E}_{4}$ and maximum of $4.42 \mathrm{mg} / 100 \mathrm{~g}$ in $\mathrm{E}_{1}$; in murici-pitanga fruits, minimum of $4.72 \mathrm{mg} / 100 \mathrm{~g}$ in $\mathrm{E}_{4}$ and maximum of $9.60 \mathrm{mg} / 100 \mathrm{~g}$ in $\mathrm{E}_{5}$; and in myrtle fruits, minimum of $3.27 \mathrm{mg} / 100 \mathrm{~g}$ in $\mathrm{E}_{5}$ and maximum of $11.05 \mathrm{mg} / 100$ $\mathrm{g}$ in $\mathrm{E}_{1}$. According to Chitarra and Chitarra (2005), the decrease in CL content of fruits studied during maturation is associated with the disintegration of chromoplasts and their thylakoidal membranes, with a rapid degradation of chlorophyll, with loss of green coloration of tissues, making visible preexisting pigments and/or synthesis of new pigments responsible for the characteristic coloration of each species, or of each cultivar.

Rufino et al. (2010) studied 18 nontraditional mature tropical fruits belonging to the family Melastomataceae, analyzed the CL content of puça-preto (Mouriri pusa Gardner ex Gardner), and obtained a value of $5.6 \mathrm{mg} / 100 \mathrm{~g}$, which results were higher than those obtained for mature fruits in this experiment $\left(\mathrm{E}_{4}-1.9 \mathrm{mg} / 100 \mathrm{~g}\right)$.

Pinto et al. (2013) also found in camucamu fruits (Myrciaria dubia (Kunth) McVaugh), decreases in CL contents with fruit maturation (from 3.25 in $\mathrm{E}_{1}$ to $0.4 \mathrm{mg} / 100 \mathrm{~g}$ in $\mathrm{E}_{4}$ ). In this sense, Egea (2014) studying mature fruits native to the Atlantic Forest also obtained a reduction in the CL content for uvaia fruits (Eugenia pyriformis Cambess.) with maturation progression (from 32.26 in $\mathrm{E}_{1}$ to 15.84 $\mathrm{mg} / 100 \mathrm{~g}$ in $\mathrm{E}_{2}$ ). Although Araujo et al. (2016) also found that $\mathrm{CT}$ contents in myrtle (Eugenia gracillima Kiaersk.) decreased as maturation progressed, varying from 19.31 to $3.80 \mathrm{mg} / 100 \mathrm{~g}$, the values are higher than in myrtle fruits of this study (from 11.05 in $\mathrm{E}_{1}$ to $3.58 \mathrm{mg} / 100 \mathrm{~g}$ in $\mathrm{E}_{6}$ ).

There was a reduction of the total carotenoid (CA) content in all fruits studied with maturation advancement, except for murici-pitanga, which varied. In guajiru fruits, the minimum value obtained was $2.50 \mathrm{mg} / 100 \mathrm{~g}$ in $\mathrm{E}_{4}$ and maximum of 5.31 $\mathrm{mg} / 100 \mathrm{~g}$ in $\mathrm{E}_{1}$; in manipuça fruits, minimum of $1.27 \mathrm{mg} / 100 \mathrm{~g}$ in $\mathrm{E}_{3}$ and maximum of $3.14 \mathrm{mg} / 100$ $\mathrm{g}$ in $\mathrm{E}_{1}$; in murici-pitanga fruits, minimum of 1.87 $\mathrm{mg} / 100 \mathrm{~g}$ in $\mathrm{E}_{4}$ and maximum of $6.13 \mathrm{mg} / 100 \mathrm{~g}$ in $\mathrm{E}_{5}$; and in myrtle fruits, minimum of $2.28 \mathrm{mg} / 100 \mathrm{~g}$ in $\mathrm{E}_{3}$ and maximum of $5.81 \mathrm{mg} / 100 \mathrm{~g}$ in $\mathrm{E}_{1}$ (Figure 1C). These results indicate that total carotenoids (CA) are already mostly synthesized in immature fruits.
Therefore, maturation advancement only revealed these pigments. This behavior is consistent with the maturation of banana (Musa sp.), where chlorophyll degradation is the main event, whereas the synthesis of other pigments is performed at relatively low levels (CHITARRA; CHITARRA, 2005).

Knowing that $\beta$-carotene (pro-vitamin A) will be transformed in the human body into vitamin A (retinol) after ingestion from the CA content of the native fruits studied, it has been found that all will partially meet the need for IDR of vitamin A for adults, which is $600 \mu \mathrm{g}$ retinol (RE) according to RDC. 269 (BRASIL, 2005), because they contain this amount in more than $100 \mathrm{~g}$ of tissue. Therefore, if the lowest and the highest CA value detected in this research is considered, and that all contents are of provitamin $\mathrm{A}$, to meet this need it will be necessary to ingest $562.42 \mathrm{~g}$ of manipuça pulp and $116.50 \mathrm{~g}$ of murici-pitanga pulp.

Rufino et al. (2010) evaluated the bioactive compounds of 18 mature, non-traditional tropical fruits and observed CA for the following Melastomataceae species: gurguri (Mouriri guianensis Aubl.), obtaining $4.7 \mathrm{mg} / 100 \mathrm{~g}$; puça-preto (Mouriri pusa Gardner ex Gardner) with $4.2 \mathrm{mg} / 100 \mathrm{~g}$ and puçacoroa-de-frade fruits (Mouriri elliptica Mart.) with $3.4 \mathrm{mg} / 100 \mathrm{~g}$; which results are higher to those obtained in mature manipuça fruits in this research $\left(\mathrm{E}_{4}-2.53 \mathrm{mg} / 100 \mathrm{~g}\right)$.

Aquino et al. (2011) studied varieties of mature acerola fruit and obtained $347.52 \mathrm{mg} / 100$ $\mathrm{g} \mathrm{CA}$, which is higher than the value found for the mature murici-pitanga fruits in this trial $\left(\mathrm{E}_{5}-6.13\right.$ $\mathrm{mg} / 100 \mathrm{~g})$.

Rufino et al. (2010) also investigated the CA content of uvaia when evaluating the bioactive compounds of 18 non-traditional mature tropical fruits, obtaining a value of $1.7 \mathrm{mg} / 100 \mathrm{~g}$, which is lower than the value obtained in mature myrtle fruits in this study $\left(\mathrm{E}_{5}-2.92 \mathrm{mg} / 100 \mathrm{~g}\right)$. Araujo et al. (2016) found that the CA content increased in myrtle fruits (Eugenia gracillima Kiaersk.) with maturation advancement (from 81.00 to $129.8 \mathrm{mg} / 100 \mathrm{~g}$ ). This behavior is contrary to the behavior observed in this research with myrtle, because a reduction in CA content was observed with maturation advance and the values are far lower.

The content of total anthocyanins (AN) decreases with maturation advancement in guajiru fruits and increases in myrtle fruits. However, in murici-pitanga fruits, it decreases up to $E_{5}$ and increases in $\mathrm{E}_{6}$, while in manipuça fruits, it increases up to $\mathrm{E}_{3}$ and decreases up to $\mathrm{E}_{5}$. The following values were obtained: guajiru fruits, minimum of 
$1.93 \mathrm{mg} / 100 \mathrm{~g}$ in $\mathrm{E}_{4}$ and maximum of $6.1 \mathrm{mg} / 100$ $\mathrm{g}$ in $\mathrm{E}_{1}$; in manipuça fruits, minimum of 1.40 in $\mathrm{E}_{5}$ and maximum of $4.73 \mathrm{mg} / 100 \mathrm{~g}$ in $\mathrm{E}_{3}$; in the murici-pitanga fruits, minimum of $1.49 \mathrm{mg} / 100 \mathrm{~g}$ in $\mathrm{E}_{5}$ and maximum of $7.99 \mathrm{mg} / 100 \mathrm{~g}$ in $\mathrm{E}_{2}$; and in myrtle fruits, minimum of $1.05 \mathrm{mg} / 100 \mathrm{~g}$ in $\mathrm{E}_{2}$ and maximum of $3.64 \mathrm{mg} / 100 \mathrm{~g}$ in $\mathrm{E}_{5}$ (Figure 1D). These results indicate that myrtle fruits showed a significant synthesis of anthocyanins during maturation, while for guajiru, there was only degradation. On the other hand, for murici-pitanga, there was initially degradation and then a significant synthesis; however, for manipuça fruits, there was initially synthesis and then degradation. The rapid accumulation of these pigments in the final maturation stages of muricipitanga (red) and myrtle (dark red) fruits yielded a more attractive appearance. The behavior of myrtle maturation corroborates that of apple (Malus domestica Borkh.), where changes in the bark color are preferentially due to the synthesis of anthocyanins than to a great chlorophyll degradation (CHITARRA; CHITARRA, 2005).

Aquino et al. (2011) studied varieties of mature acerola fruits and obtained $50.73 \mathrm{mg} / 100 \mathrm{~g}$ $\mathrm{AN}$, which is higher in relation to mature muricipitanga fruits of this research $\left(\mathrm{E}_{5}-1.49 \mathrm{mg} / 100 \mathrm{~g}\right)$.

Rufino et al. (2010) reported $143 \mathrm{mg} / 100$ g AN in myrtle fruits (Blepharocalyx salicifolius (Kunth) O.Berg), a value well above the maximum found in this work for mature myrtle $\left(E_{5}-3.64 \mathrm{mg} / 100\right.$ g). In this sense, Rocha et al. (2013) investigated mature fruits of the Piauí Cerrado, among them cagaita (Eugenia dysenterica DC.) and obtained 0.38 $\mathrm{mg} / 100 \mathrm{~g}$ of AN, which is lower than that obtained for mature myrtle fruits of this work. Araujo et al. (2016) observed that the AN content in myrtle fruits (Eugenia gracillima Kiaersk.) increased greatly with maturation advance, ranging from 4.94 to 125.82 $\mathrm{mg} / 100 \mathrm{~g}$. This behavior ratifies the present research, because myrtle fruits studied in this research showed an increase in AN contents with maturation progress, although with values much lower.

The content of yellow flavonoids (FL) in all fruits studied decreased with maturation, except for guajiru, which increased up to $\mathrm{E}_{3}$ and then decreased up to $E_{5}$. A minimum value of $3.50 \mathrm{mg} / 100 \mathrm{~g}$ at $\mathrm{E}_{4}$ and maximum of $27.55 \mathrm{mg} / 100 \mathrm{~g}$ at $\mathrm{E}_{3}$ was obtained for guajiru fruits; in manipuça fruits, minimum of $6.22 \mathrm{mg} / 100 \mathrm{~g}$ at $\mathrm{E}_{5}$ and maximum of $18.03 \mathrm{mg} / 100$ $\mathrm{g}$ at $\mathrm{E}_{1}$; in murici-pitanga fruits, minimum of 14.59 $\mathrm{mg} / 100 \mathrm{~g}$ at $\mathrm{E}_{5}$ and maximum of $61.59 \mathrm{mg} / 100 \mathrm{~g}$ at $\mathrm{E}_{2}$; and in myrtle fruits, minimum of $25.52 \mathrm{mg} / 100 \mathrm{~g}$ at $E_{3}$ and maximum of $69.11 \mathrm{mg} / 100 \mathrm{~g}$ at $\mathrm{E}_{2}$ (Figure $1 \mathrm{E})$. These results indicate that for all fruits, there was
FL degradation during the fruit maturation, whereas for guajiru fruits, there was initially synthesis and then degradation.

According to Davies and Schwinn (2006), the production of flavonoids is induced through various forms of stress, such as exposure to ultraviolet radiation, injury, pathogen infection, light incidence or nutrient deficiency, generating an increase in the capture of free radicals, to increase fruit defense. All analyzed fruits were under conditions of high luminous intensity.

Silveira (2008) analyzed the FL of 15 genotypes of mature puça-coroa-de-frade fruits and obtained in genotypes 12 and 13, the lowest values, $5.33 \mathrm{mg} / 100 \mathrm{~g}$ and $5.67 \mathrm{mg} / 100 \mathrm{~g}$, respectively, and for genotype 17 the highest value, $11.93 \mathrm{mg} / 100 \mathrm{~g}$; the smaller results mentioned above are lower than those obtained for mature manipuça fruits in this research $\left(E_{4}-10.92 \mathrm{mg} / 100 \mathrm{~g}\right)$, while the greatest is higher.

Barreto (2008) analyzed 18 pulps of mature tropical fruits and observed FL content of 319.4 $\mathrm{mg} / 100 \mathrm{~g}$ for murici (Byrsonima crassifolia (L.) Kunth); therefore, this value is higher than that obtained for mature murici-pitanga fruits (Byrsonima gardneriana A. Juss.) in this work $\left(\mathrm{E}_{5}-14.59 \mathrm{mg} / 100\right.$ $\mathrm{g}$ ), and the difference can be attributed to the species and consequently to the fruit coloration when mature, which is yellow in murici and red in murici-pitanga.

Rocha et al. (2013) studied mature cagaita fruits and obtained FL content of $9.51 \mathrm{mg} / 100 \mathrm{~g}$, which is lower than that obtained for mature myrtle fruits of this work $\left(E_{5}-28.26 \mathrm{mg} / 100 \mathrm{~g}\right)$, On the other hand, the FL values found in this work were lower than those of mature myrtle $(207.0 \mathrm{mg} / 100 \mathrm{~g})$ (Blepharocalyx salicifolius (Kunth) O.Berg) in the study by Rufino et al. (2010). In this sense, Araujo et al. (2016) found a decrease in FL content of myrtle fruits (Eugenia gracillima Kiaersk.) with maturation progression up to $\mathrm{E}_{4}$ (from 70 to $50 \mathrm{mg} / 100 \mathrm{~g}$ ), followed by an increase in $\mathrm{E}_{5}$ (from $70 \mathrm{mg} / 100 \mathrm{~g}$ ) . This behavior differs from that obtained with myrtle in the present research, where the FL content was decreasing with maturation advancement.

Murici-pitanga fruits showed higher AA, CA and $A N$ values; and myrtle fruits showed higher $\mathrm{CL}$ and FL values.

Among the maturation stages of muricipitanga fruits, stage 5 is superior in AA, stage 5 in CA and stage 2 in AN.

For myrtle, the highest values are found for stage 1 for CL; 1 and 2 for FL.

There was no significant correlation between variables in guajiru fruits; in manipuça fruits, there 
was a positive and significant correlation between the $\mathrm{CL}$ and $\mathrm{CA}$, with $\mathrm{R}=0.99^{* *}$; in murici-pitanga fruits, there was a positive and significant correlation between $\mathrm{AN}$ and $\mathrm{FL}$ variables with $\mathrm{R}=0.97$; in myrtle fruits, there was a negative and significant correlation between variables AA and FL, with $\mathrm{R}=-0.98^{*}$. Therefore, the CL and CA contents in manipuça fruits, and AN and FL in murici-pitanga fruits are directly proportional; however, between AA and FL in myrtle fruits, values are inversely proportional. Thus, if we know the content of one of these bioactive compounds that has significant correlation, we can predict the magnitude of the other content, since the linear correlation measures the degree of association between them (Table 1).

Rufino et al. (2010) worked with 18 Brazilian non-traditional tropical fruit species and found positive and significant correlations between $\mathrm{CL}$ and CA variables with $\mathrm{R}=0.93^{*}$; $\mathrm{AN}$ and $\mathrm{FL}$ with $\mathrm{R}=$
$0.67^{* *}$, which results corroborate this research, since we obtained for these same correlations $\mathrm{R}=0.99 * *$ (in manipuça) and $\mathrm{R}=0.97$ * (in murici-pitanga), respectively.

Lucena (2006) obtained negative and significant correlation in "Tommy Atkins" mango fruits between variables AA and CA with $\mathrm{R}=-0.43^{*}$; however, in this research, guajiru, manipuça, muricipitanga and myrtle fruits showed no significant correlation $\left(\mathrm{R}=0.47^{\mathrm{ns}} ; \mathrm{R}=-0.31^{\mathrm{ns}} ; \mathrm{R}=-0.79^{\text {ns; }} ; \mathrm{R}=\right.$ $-0.22^{\text {ns }}$, respectively) for this correlation. On the other hand, Lucena (2006) did not detect significant correlation between $\mathrm{CL}$ and $\mathrm{CA}$ variables with $\mathrm{R}=$ $-0.02^{\text {ns }}$, corroborating the results of this study for the same correlation for guajiru $\left(\mathrm{R}=-0.16^{\mathrm{ns}}\right)$, muricipitanga $\left(\mathrm{R}=-0.20^{\mathrm{ns}}\right)$ and myrtle $\left(\mathrm{R}=0.40^{\mathrm{ns}}\right)$, although it differed for manipuça, which was positive and significant $(\mathrm{R}=0.99 * *)$.

TABLE 1 - Correlation matrix among ascorbic acid (AA), chlorophyll (CL), carotenoids (CA), anthocyanin (AN) and flavonoids (FL) of guajiru (Chrysobalanus icaco L.), manipuça (Mouriri cearensis Huber.) , murici-pitanga (Byrsonima gardneriana A. Juss.) and myrtle fruits (Eugenia punicifolia (Kunth) DC.) at different maturation stages.

\begin{tabular}{|c|c|c|c|c|}
\hline Variables & $\mathrm{CL}$ & $\mathrm{CA}$ & AN & FL \\
\hline \multicolumn{5}{|l|}{ Guajiru } \\
\hline AA & $0.78^{\text {ns }}$ & $0.47^{\mathrm{ns}}$ & $-0.61^{\mathrm{ns}}$ & $0.52^{\mathrm{ns}}$ \\
\hline $\mathrm{CL}$ & - & $-0.16^{\text {ns }}$ & $-0.55^{\mathrm{ns}}$ & $0.93^{\text {ns }}$ \\
\hline $\mathrm{CA}$ & - & - & $-0.18^{\mathrm{ns}}$ & $-0.49^{\mathrm{ns}}$ \\
\hline AN & - & - & - & $-0.43^{\mathrm{ns}}$ \\
\hline \multicolumn{5}{|l|}{ Manipuça } \\
\hline AA & $-0.39^{\text {ns }}$ & $-0.31^{\mathrm{ns}}$ & $-0.93^{\text {ns }}$ & $0.79^{\text {ns }}$ \\
\hline $\mathrm{CL}$ & - & $0.99^{* *}$ & $0.69^{\text {ns }}$ & $0.24^{\mathrm{ns}}$ \\
\hline CA & - & - & $0.62^{\text {ns }}$ & $0.32^{\text {ns }}$ \\
\hline AN & - & - & - & $-0.52^{\mathrm{ns}}$ \\
\hline \multicolumn{5}{|c|}{ Murici-pitanga } \\
\hline $\mathrm{AA}$ & $0.75^{\text {ns }}$ & $-0.79^{\text {ns }}$ & $-0.07^{\mathrm{ns}}$ & $-0.29^{\text {ns }}$ \\
\hline $\mathrm{CL}$ & - & $-0.20^{\text {ns }}$ & $0.58^{\mathrm{ns}}$ & $0.39^{\text {ns }}$ \\
\hline $\mathrm{CA}$ & - & - & $0.66^{\mathrm{ns}}$ & $0.81^{\mathrm{ns}}$ \\
\hline AN & - & - & - & $0.97^{*}$ \\
\hline \multicolumn{5}{|l|}{ Murta } \\
\hline AA & $-0.16^{\text {ns }}$ & $-0.22^{\text {ns }}$ & $-0.87^{\mathrm{ns}}$ & $-0.98^{*}$ \\
\hline $\mathrm{CL}$ & - & $0.40^{\mathrm{ns}}$ & $-0.33^{\text {ns }}$ & $0.01^{\mathrm{ns}}$ \\
\hline $\mathrm{CA}$ & - & - & $0.00^{\text {ns }}$ & $0.12^{\text {ns }}$ \\
\hline AN & - & - & - & $0.93^{\text {ns }}$ \\
\hline
\end{tabular}

*,**Significant, respectively, at level of 5 and of $1 \%$ of probability, by the test $t$.

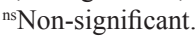



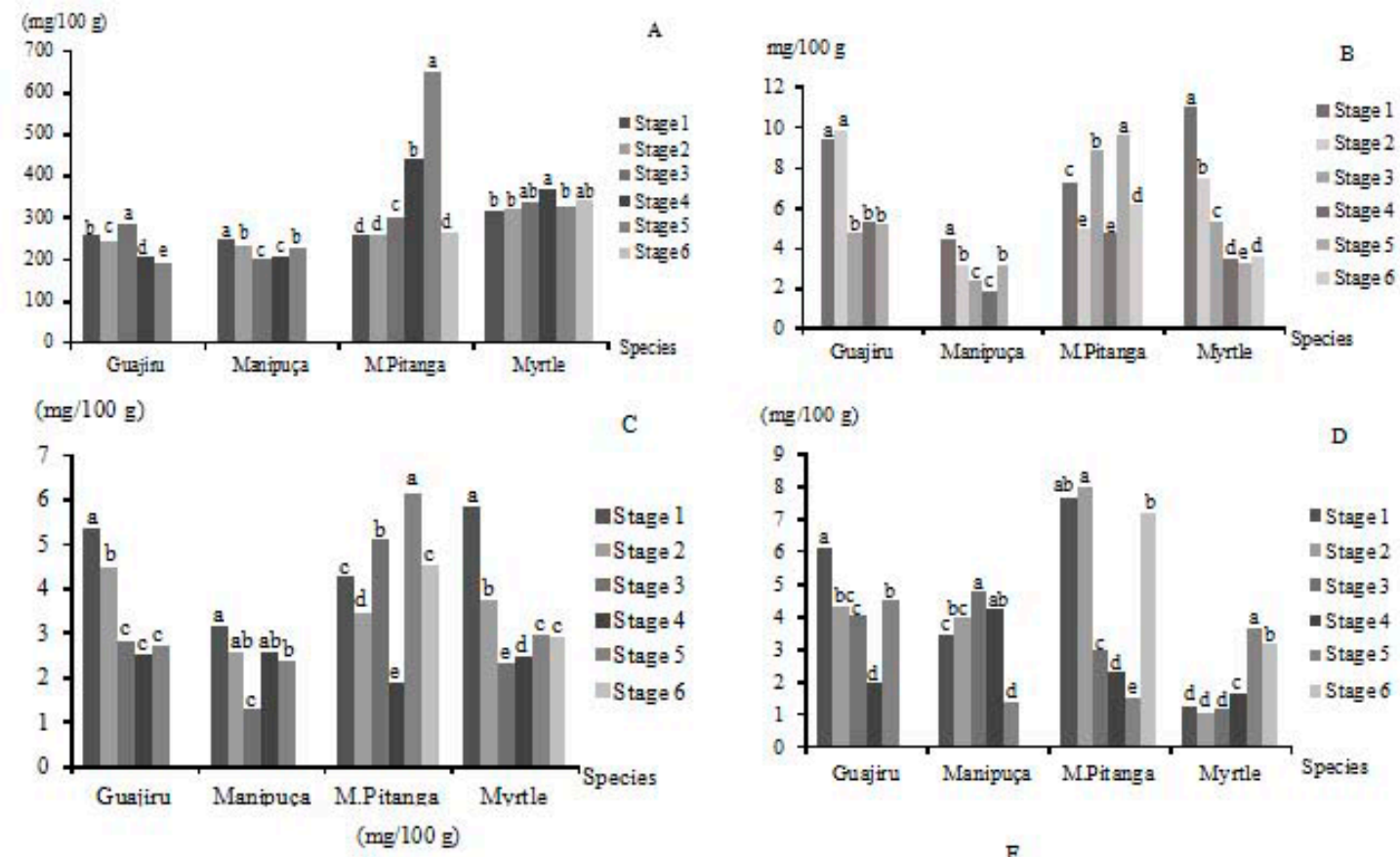

(mg/100 g)
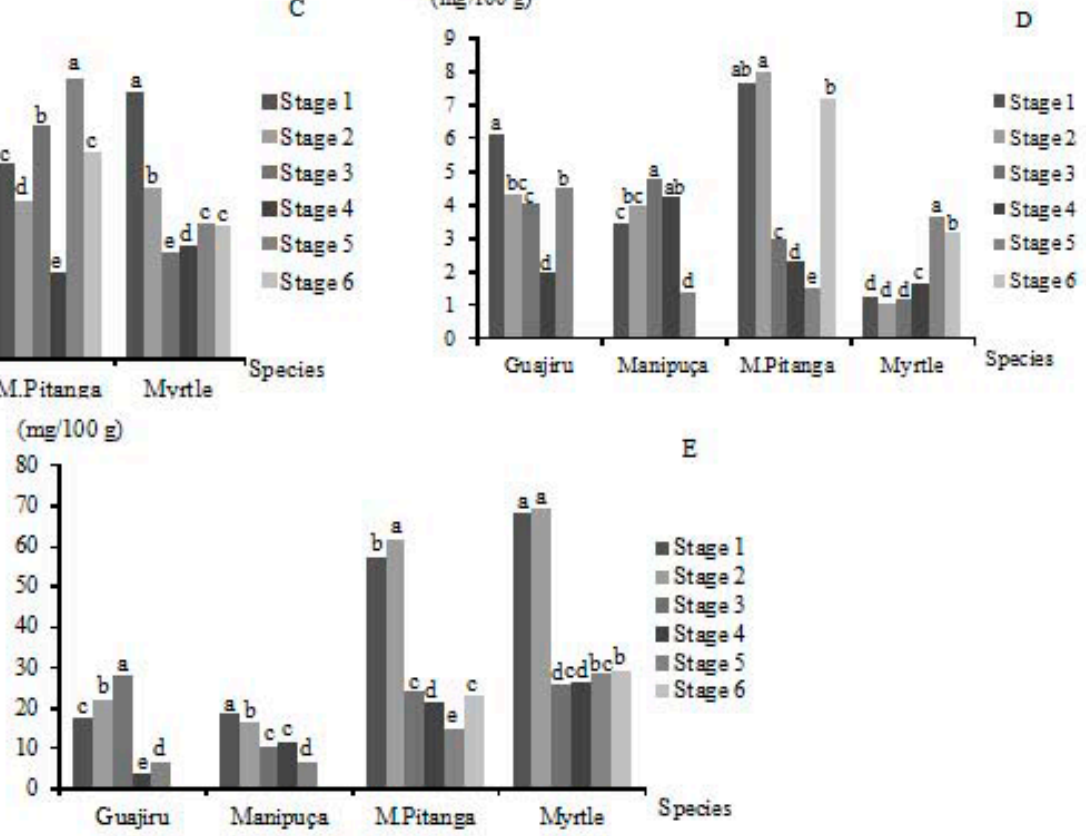

FIGURE 1 - A - Ascorbic acid (mg/100 g); B - Chlorophyll (mg/100 g); C - Total carotenoids (mg/100 g); D - Total anthocyanins (mg/100 g); E - Yellow flavonoids (mg/100 g); of guajiru (Chrysobalanus icaco L.), manipuça (Mouriri cearensis Huber.), murici-pitanga (Byrsonima gardneriana A. Juss.) and myrtle fruits (Eugenia punicifolia (Kunth) DC.) at different maturation stages.

*Means followed by the same letter in the same species do not differ from each other by the Tukey test at $5 \%$ probability level. 


\section{CONCLUSIONS}

The content of ascorbic acid in myrtle fruits was increasing with maturation advancement, while in guajiru and in manipuça fruits, it was decreasing. On the other hand, in murici-pitanga fruits, the content of ascorbic acid increased up to the climacteric peak and later it decreased in the senescence.

The total chlorophyll was decreasing with maturation advancement in guajiru, manipuça and myrtle fruits; however, it varied in murici-pitanga.

The total carotenoids decreased with the maturation of guajiru and myrtle fruits, while it varied for murici-pitanga and for manipuça, it decreased up to reaching the physiological maturity and later it grew up to senescence.

The total anthocyanins increased with the maturation of myrtle fruits and decreased for guajiru fruits. On the other hand, in murici-pitanga fruits, it decreased up to the climacteric peak and later it grew during senescence, whereas in manipuça fruits, it grew up to reaching the physiological maturity and then it decreased up to senescence.

The levels of yellow flavonoids in manipuça, murici-pitanga and myrtle fruits decreased with maturation, while in guajiru fruits, they increased up to reaching physiological maturity and then decreased up to senescence.

The ideal maturation stage for harvest will depend on which bioactive compound one wants to explore, because for compounds that increase with maturation advance, the harvest can be done in the last stage; however, for those that decrease, the first maturation stage is recommended, although we know that these are not the ideal harvest points for human consumption.

Murici-pitanga and myrtle have the highest contents of bioactive compounds; therefore, both fruits can be recommended to be commercially exploited by the food, cosmetic and phytotherapeutic sectors.

\section{ACKNOWLEDGEMENTS}

To the Foundation to Support Scientific and Technological Development of Ceara (FUNCAP) for granting the Master's Degree scholarship to the first author; the National Council for Scientific and Technological Development $(\mathrm{CNPq})$ and Banco do Nordeste (BNB) for financial support for the research project; Embrapa Agroindústria Tropical for technical support; to the Botanical State Park of Ceara and to the Botanic Garden of São Gonçalo for the logistical support.

\section{REFERENCES}

AQUINO, A.C.M.S.; MÓES, R.S.; CASTRO, A.A. Estabilidade de ácido ascórbico, carotenoides e antocianinas de frutos de acerola congelados por métodos criogênicos. Brazilian Journal of Food Technology, Campinas, v.14, n.2, p.154-163, 2011.

ARAUJO, D.R. de; LUCENA, E.M.P. de; GOMES, J.P.; FIGUEIRÊDO, R.M.F. de; SILVA, C.P. da. Characterization of ripening stages of myrtle fruit. Revista Brasileira de Fruticultura, Jaboticabal, v.38, n.2, p.e-712, 2016.

BARRETO, G.P.M. Carotenoides e compostos bioativos: relação com propriedades antirradical livre e corante em frutas tropicais. 2008. $189 \mathrm{f}$. Tese (Doutorado em Ciência de Alimentos)- Universidade Estadual de Campinas, Campinas, 2008.

BRASIL. Ministério da Saúde. Agência Nacional de Vigilância Sanitária. Resolução RDC no 269 , de 22 de setembro de 2005. Regulamento técnico sobre a ingestão diária recomendada (IDR) de proteína, vitaminas e minerais. Brasília, 2005. Disponível em: <http://portal.anvisa.gov. br/documents/33916/394219/RDC 269 2005. pdf/2e95553c-a482-45c3-bdd1-f96162d607b3>. Acesso em: 27 dez. 2016.

BRASIL. Ministério da Saúde. Secretaria de Atenção à Saúde. Coordenação-Geral da Política de Alimentação e Nutrição. Guia alimentar para a população brasileira: promovendo a alimentação saudável. Brasília: Ministério da Saúde, 2006. 210p. (Série A. Normas e Manuais Técnicos).

CASTRO, A.H.F.; BRAGA, K. de Q.; SOUSA, F.M. de; COIMBRA, M.C.; CHAGAS, R.C.R. Callus induction and bioactive phenolic compounds production from Byrsonima verbascifolia (L.) DC. (Malpighiaceae). Revista Ciência Agronômica, Fortaleza, v.47, n.1, p.143-151, 2016.

CAVALINI, F.C.; JACOMINO, A.P.; TREVISAN.M.J.; MIGUEL, A.C.A. Ponto de colheita e qualidade de goiabas 'Kumagai' e 'Paluma'. Revista Brasileira de Fruticultura, Jaboticabal, v. 37, n. 1, p.64-72, 2015. 
Chitarra, M. I. F.; CHITARRA, A. B. Póscolheita de frutas e hortaliças: fisiologia e manuseio. 2. ed. rev. e ampl. Lavras: UFLA, 2005. $785 \mathrm{p}$.

DAVIES, K.M.; SCHWINN, K.E. Molecular biology and biotechnology of flavonoid biosynthesis. In: ANDERSEN, O.M.; MARKHAM, K.R. Flavonoids: chemistry, biochemistry. New York: Taylor \& Francis Group, 2006. cap.3, p.143-162.

EGEA, M.B. Frutos nativos da floresta atlântica com potencial de maior utilização pela população e pela indústria: caracterização nutracéutica e aromática. 2014. 136 f. Tese (Doutorado em Engenharia de Alimentos) - Universidade Federal do Paraná, Curitiba, 2014.

FRANCIS, F.J. Analysis of anthocyanins. In: MARKAKIS, P. (Ed.). Anthocyanins as food colors. New York: Academic Press, 1982. p.181-207.

FUNCEME - Fundação Cearense de Meteorologia e Recursos Hídricos. Calendário das chuvas no Estado do Ceará. Fortaleza, 2015. Disponível em: $<$ http://www.funceme.br/app/calendario/produto/ $\underline{\text { municipios } / \text { maxima/diario?data }=2015-2-3}>$. Acesso em: 25 jan. 2015.

GARCIA, R.C.G.; GOMES, J.P.; LUCENA, E.M.P. de; ALVES, N.M.C.; SANTOS, D.C.; OLIVEIRA, E.N.A. Parâmetros físico-químicos dos frutos de manipuçá em cinco estádios de maturação. Revista Educação Agrícola Superior, Brasília, v.26, p.109112, 2011.

IPECE - Instituto de Pesquisa e Estratégia Econômica do Ceará. Perfil básico. Fortaleza, 2015. Disponível em: <http://www.ipece.ce.gov.br/publicacoes/ perfil basico/index perfil basico.htm $>$. Acesso em: 25 jan. 2015.

KOTTEK, M.; GRIESER, J.; BECK, C.; RUDOLF, B.; RUBEL, F. World map of Köppen-Geiger climate classification updated. Meteorologische Zeitschrift, Berlin, v.15, n.3, p.259-263, 2006.

KRUMREICH, F.D.; CORRÊA, A.P.A.; SILVA, da S.D.S.; ZAMBIAZI, R.C. Composição físicoquímica e de compostos bioativos em frutos de Bromelia antiacantha Bertol. Revista Brasileira de Fruticultura, Jaboticabal, v.37, n.2, p.450-456, 2015.
LICHTENTHALER, H.K. Chlorophylls and carotenoids: pigments of photosynthetic biomembranes. Methods in Enzymology, San Diego, v.148, n.22, p.350-382, 1987.

LIMA, J.S.S.; CASTRO, J.M.C. de; SABINO, L.B.S.; LIMA, A.C.S. de; TORRES, L.B.V. Physicochemicalproperties of gabiroba (Campomanesia lineatifolia) and myrtle (Blepharocalyx salicifolius) native to the mountainous region of Ibiapaba - CE, Brazil. Revista Caatinga, Mossoró, v.29, n.3, p.753-757, 2016.

LUCENA, E.M.P. de. Desenvolvimento e maturidade fisiológica de manga "Tommy Atkins" no vale do São Francisco. 2006. 152 f. Tese (Doutorado em Agronomia) - Universidade Federal do Ceará, Fortaleza, 2006.

LUCENA, E.M.P. de; MAJOR. I.; BONILLA, O.H. Frutas do litoral cearense. Fortaleza: EdUECE, 2011. 112p.

MORAIS, D.R.; ROTTA, E.M.; SARGI, S.C.; SCHMIDT, E.M.; BONAFE, E.G.; EBERLIN, M.N.; SAWAYA, A.C.H.F.; VISENTAINER, J.V. Antioxidant activity, phenolics and UPLC-ESI(-)MS of extracts from different tropical fruits parts and processed peels. Food Research International, Barking, v.77, n.3, p.392-399, 2015.

PINTO. P. M.; JACOMINO. A. P.; SILVA, S. R.; ANDRADE, C. A. W. Ponto de colheita e maturação de frutos de camu-camu colhidos em diferentes estádios. Pesquisa Agropecuária Brasileira, Brasília, DF, v.48, n.6, p.605-612, 2013.

ROCHA, M.S.; FIGUEIREDO, R.W. de; ARAUJO, M.A. da M.; MOREIRA-ARAUJO, R.S. dos R. Caracterização físico-química e atividade antioxidante (in vitro) de frutos do cerrado Piauiense. Revista Brasileira de Fruticultura, Jaboticabal, v.35, n.4, p.933-941, 2013.

RUFINO, M. do S.M.; ALVES, R.E.; BRITO, E.S. de; PÉREZ-JIMÉNEZ J.; SAURACALIXTO, F.; MANCINI-FILHO, J. Bioactive compounds and antioxidant capacities of 18 non-traditional tropical fruits from Brazil. Food Chemistry, Reading, v.121, p.996-1002, 2010. 
SILVEIRA, M.R.S. da. Qualidade e atividade antioxidante de frutos de genótipos de puçazeiro "Coroa de Frade" (Mouriri elliptica Mart.) da vegetação litorânea do Ceará. 2008. 117f. Dissertação (Mestrado em Tecnologia de Alimentos) - Universidade Federal do Ceará, Fortaleza, 2008.

SMIRNOFF, N.; CONKLIN, P.; LOEWUS, F.A. Biosynthesis of ascorbic acid in plants: a renaissance. Annual Review of Plant Physiology and Plant Molecular Biology, Palo Alto, v.52, p.437-467, 2001.
SOUZA, K.O. de; MOURA, C.F.H.; BRITO, E.S. de; MIRANDA, M.R.A. de. Antioxidant compounds and total antioxidant activity in fruits of acerola from cv. Flor Branca, Florida Sweet and BRS 366. Revista Brasileira de Fruticultura, Jaboticabal, v.36, n.2, p.294-304, 2014.

STROHECKER, R.; HENNING, H.M. Analisis de vitaminas: métodos comprobados. Madrid: Paz Montalvo, 1967. 428p.

WHEELER, G.L.; JONES, M.A.; SMIRNOFF, N. The biosynthetic pathway of vitamin $\mathrm{C}$ in higher plants. Nature, London, v.393, p.365-369, 1998. 